\title{
PERANAN CAMAT DALAM MEMBINA ADMINISTRASI PEMERINTAHAN DESA DI KECAMATAN BENAI KABUPATEN KUNTAN SINGINGI
}

\author{
Sahri Muharam ${ }^{1}$, Alsar Andri ${ }^{2}$ dan Askarmin Harun ${ }^{3}$ \\ ${ }^{1}$ Program Studi Administrasi Negara ,Fakultas Ilmu Sosial, Universitas Islam Kuantan Singingi, Indonesia \\ sahrimuharam65o@gmail.com \\ ${ }^{2}$ Program Studi Administrasi Negara, Fakultas Ilmu Sosial, Universitas Islam Kuantan Singingi, Indonesia \\ alsar_andri@yahoo.co.id \\ ${ }^{3}$ Program Studi Ilmu Pemerintahan, Fakultas Ilmu Sosial dan Politik, Universitas Riau Kepulauan, Indonesia \\ askarmin@rocketmail.com
}

\begin{abstract}
Abstrak
Ketidakseriusan desa dalam pengadminsitrasian dapat dilihat pada tidak tertatanya buku administrasi secara baik, adanya sekretaris desa yang ditetapkan berstatus Pegawai Negeri Sipil (PNS atau sekarang lebih dekat dengan sebutan Aparatur Sipil Negara), adanya penempatan pendamping desa dan banyak di antara desa yang ingin mengubah statusnya ke kelurahan kesemuan ini dikarenakan berawal ketidakmapanan desa dalam pengadministrasian.Penelitian ini bertujuan untuk mengetahui peranan camat dan faktor-faktor penghambat dalam membina administrasi Pemerintahan Desa di Kecamatan Benai Kabupaten Kuntan Singingi.Metode penelitian ini menggunakan penelitian survey dengan tingkat eksplanasi deskriftif dan menggunakan analisa data kuantitatif dan kualitatif. Penelitian ini melihat mengenai peranan camat yang tertuang dalam Peraturan Pemeritah Nomor 19 Tahun 2008 Tentang Kecamatan Pasal 15 Ayat 1 Butir F dan Ayat 2 Butir D yakni, membina atau pembinaa penyelenggaraan pemerintahan desa dan/ataukelurahan Demi efisiensi dan efektivitas penyelenggaraan pemerintahan desa.Dilihat dari hasil penelitian rekapan bahwasaannya camat kurang berperan dalam pembinaan yang terkhusus pada pembinaan administrasi yang berada pada kategori angka $43 \%$.
\end{abstract}

Kata Kunci : Pembinaan, Administrasi, Pemerintahan, Desa.

\begin{abstract}
The vilage's lack of seriousness in administration can be seen in the lack of a well organized administration book, the existence village secretary who is assigned the status of a civil servent (PNS or now closer to the State Civil Aparatur), the placement of village assistants and many of the village's who wan to change their status to the kelurahan of this meeting was due to beginning of the village's incompetence in admninstration. This study aims to determine the role of the camat and the inhibiting factors in fostering the administration of the village the government in Benai District Kuantan Singingi Regency. This research method used surveyresearch with descriptive explanatory level and using quantitative and qualitative data analysis. This study looks at the role of the camat as stipulated in the Government Regulation Number 19 of 2008 concerning District Article 15 Paragraph 1 Point $F$ and Paragraph 2 Point D, namely fostering the administration of village and/or kelurahan government. Judging from the result of the study, the sub district camat did not play a role in coaching specifically in administrative coaching in the $43 \%$ category.

Keyword: Village Government Adminstration Development.
\end{abstract}




\section{PENDAHULUAN}

Dalam sistem ketatanegaraan Indonesia, desa adalah subsistem pemerintahan daerah di bawah subsistem pemerintahan nasional.Desa adalah satuan administrasi pemerintahan terendah dengan hak otonomi berbasis asal usul dan adat istiadatnya.Oleh karena itu, penyelenggaraan pemerintahan desa harus tetap terintegrasi dalam subsistem administrasi daerah dan sistem administrasi negara kesatuan Republik Indonesia.Untuk menjaga agar penyelenggaraan pemerintahan desa tetap terintegrasi dalam subsistem administrasi daerah dan sistem pemerintahan nasional maka perlu dilakukan pembinaan terhadap pemerintah desa. Pembinaan atas penyelenggaraan pemerintahan desa adalah upaya yang dilakukan oleh pemerintah, pemerintah propinsi, dan pemerintah kabupaten/kota kepada desa agar penyelenggaraan pemerintahan desa berjalan sesuai dengan tujuannya, adapun yang berperan dalam pembinaan administrasi pemerintahan desa sebagai mana yang tertuang dalam Peraturan Pemeritah Nomor 19 Tahun 2008 Tentang Kecamatan adalah pemerintahan kecamatan.

Dalam Peraturan Pemeritah Nomor 19 Tahun 2008 Tentang Kecamatan yang termaktub pada Bab IV mengenai kedudukan, tugas dan wewenang Pasal 15 Ayat 1 dan 2 menyatakan tugas camat sebagai berikut:

Camat menyelenggarakan tugas umum pemerintahan yangmeliputi:

a. Mengoordinasikan kegiatan pemberdayaan masyarakat;

b. Mengoordinasikan upaya penyelenggaraan ketenteraman dan ketertiban umum;

c. Mengoordinasikan penerapan dan penegakan peraturan perundang undangan;

d. Mengoordinasikan pemeliharaan prasarana dan fasilitaspelayanan umum;

e. Mengoordinasikan penyelenggaraan kegiatan pemerintahan di tingkat kecamatan;

f. Membina penyelenggaraan pemerintahan desa dan/ataukelurahan; dan

g. Melaksanakan pelayanan masyarakat yang menjadi ruang lingkup tugasnya dan/atau yang belum dapat dilaksanakan pemerintahan desa atau kelurahan.

Selain tugas sebagaimana dimaksud pada ayat (1) Camat melaksanakan kewenangan pemerintahan yangdilimpahkan oleh bupati/walikota untuk menanganisebagian urusan otonomi daerah, yang meliputi aspek:
a. Perizinan;
b. Rekomendasi;
c. Koordinasi; 

d. Pembinaan;
e. Pengawasan;
f. Fasilitasi;
g. Penetapan;
h. Penyelenggaraan; dan
i. Kewenangan lain yang dilimpahkan.

Peranan camat dapat terlihat sebagai pembina atau melakukan pembinaan termaktub pada Pasal 15 Ayat 1 Butir F dan Ayat 2 Butir D yakni :

Ayat 1 Butir F: Membina penyelenggaraan pemerintahan desa dan/atau kelurahan demi efisiensi dan efektivitas penyelenggaraan pemerintahan desa.

Ayat 2 butir D : Pembinaan

Salah satu bentuk pembinaan yang mesti dilakukan pemerintahan kecamatan adalah melakukan pembinaan administras pemerintahan desa, karena hal ini merupakan salah satu kegiatan yang menunjang untuk terlaksananya pemerintahan desa yang baik.Pemerintah desa harus didukung dengan tata usaha ataupun sistem pengadministrasian yang benar. Tata Usaha adalah kegiatan mencatat semua proses penyelenggaraan pemerintahan desa yang disebut administrasi desa. Jadi, administrasi desa adalah keseluruhan proses kegiatan pencatatan data dan informasi mengenai penyelenggaraan pemerintahan desa pada buku administrasi desa.

Administrasi desa sangat penting bagi kegiatan penyelenggaraan pemerintahan desa. Pemerintahan desa akan berjalan dengan lancar manakala didukung oleh sistem tata usaha/administrasi yang benar, rapi, dan tertib. Sistem administrasi yang benar, rapi, dan tertib akan memberikan data dan informasi yang mudah dan sistematis yang sangat berguna untuk pengambilan keputusan, pembuatan rencana, kontrol kegiatan, evaluasi, dan komunikasi dan informasi baik ke dalam maupun keluar organisasi.

Perlunya desa mendapatkan pembianaan terlebih khusus mengenai administrasi karena pentingnya administrasi dalam mencapai kesuksesan pemerintahan desa, ketidakseriusan desa dalam pengadminsitrasian dapat dilihat pada tidak tertatanya buku administrasi secara baik, adanya sekretaris desa yang ditetapkan berstatus Pegawai Negeri Sipil (PNS atau sekarang lebih dekat dengan sebutan Aparatur Sipil Negara), adanya penempatan pendamping desa dan banyak di antara desa yang ingin mengubah statusnya ke kelurahan kesemuan ini dikarenakan berawal ketidakmapanan desa dalam pengadministrasian. 


\section{TINJAUN PUSTAKA}

1. Teori/Konsep Fungsi, Peranan dan Tugas

Bagi kebanyakan struktural-fungsionalis, fungsi adalah tugas sosial, suatu kegiatan yang harus dilaksanakan dengan tingkat ketepatan tertentu apabila ada pengelompokan sosial dan mempertahankan keanggotaan kelompoknya. Diantara tugas-tugas ini terdapat rentang wilayah kerja yang meliputi sosialisasi dan pendidikan kalangan muda, pengaturan hal ihwal ekonomi dan politik, regulasi perilaku kejahatan dan selanjutnya. (Saifuddin, 2005 : 159).

Peran (role) merupakan aspek yang dinamis dari kedudukan (status). Artinya, seseorang telah menjalankan hak-hak dan kewajiban-kewajibannya sesuai dengan kedudukannya, maka orang tersebut telah melaksanakan sesuatu peran. Keduanya tak dapat dipisahkan karena satu dengan yang lain saling tergantung, artinya tidak ada peran tanpa status dan tidak ada status tanpa peran. (Narwoko dan Suyanto, 2004 : 158-159).

Lebih lanjut Parson menerangkan tentang status dan peran. Dalam perspektif struktural-funsinalis, setiap individu menempati suatu status dalam berbagai struktur masyarakat. Status dalam hal ini bukanlah prestise dari posisi individual, melainkan posisi itu sendiri. Individu yang menempati suatu status juga dianggap memiliki hak-hak dan kewajiban-kewajiban tertentu, yang merupakan peranan dalam status tersebut. Jadi satus dan peranan cenderung berada bersama-sama dalam apa yang disebut Parson sebagai "kumpulan status dan peranan". (dalam Saifuddin, 2005 : 157).

Menurut Kamus Besar Bahasa Indonesia Pusat Bahasa Edisi Keempat tugas adalah yang wajib dikerjakan atau yang ditentukan untuk dilakukan; pekerjaan yang menjadi tanggung jawab seseorang; pegawai hendaklah menjalankan masing-masing dengan baik. (Kamus Besar Bahasa Indonesia Edisi Keempat, 2008 : 1492).

\section{Teori/Konsep Pelatihan dan Pembinaan}

Menurut Hamalik pelatihan merupakan suatu fungsi manajemen yang perlu dilaksanakan terus-menerus dalam rangka pembinaan ketenagaan dalam suatu organisasi. Sedangkan secara spesifik menurut Hamalik proses latihan itu merupakan serangkain tindakan (upaya) yang dilaksanakan secara berkesinambungan, bertahap dan terpadu. Tiap proses latihan harus terarah untuk mencapai tujuan tertentu terkait dengan upaya pencapain tujuan organisasi.(Hamalik, $2001:$ 10-11). 
Pelatihan dalam pekerjaan adalah peningkatan keahlian untuk tugas-tugas dan aktivitas yang diperlukan di posisi tertentu. (Usmara, $2006: 6$ ).

Program pelatihan itu efektif hanya jika program-program tersebut berhubungan dengan kebutuhan-kebutuhan keterampilan atau pengetahuan yang berlaku (Usmara, 2006 : 72).

Tujuan pelatihan :

1. Agar organisasi bisa bersaing.

2. Mengembangkan keterampilan dan kompetensi karyawan.

3. Memperkuat komitmen karyawan. (Usmara, 2006 : 72).

Analisis kebutuhan pelatihan:

1. Analisis organisasi.

2. Analisis operasi.

3. Analisis personal.(Usmara, $2006: 74)$.

Model Pelatihan :

1. Pengembangan pola pikir bersama untuk membangun kapabilitas organisasional melalui SDM.

2. Harus ada suatu komitmen fundamental dan keyakinan dalam pendidikan, pelatihan dan pengenmbangan SDM.

3. Aktivitas-aktivitas pelatihan dan pengembangan harus dihubungkan dengan strategi dan sasaran bisnis.

4. Pelatiahan dan pengembangan berfokus pada kebutuhan organisasional yang telah didefinisikan dengan jelas.

5. Pelatihan dapat meningkatkan keunggulan kompetitif jika karyawan mendapat pengetahuan dan keterampilan serta mampu menggunakan kompetensinya.

6. Penetapan sasaran yang tepat untuk untuk pelatihan berdasarkan perubahan dan hasil yang diinginkan.

7. Pemerincian spesifikasi-spesifikasi pelatihan.

8. Pengevaluasian menyeluruh dari pelatihan dan komitmen dari semua partisipan terhadap proses tersebut. (Usmara, $2006: 83$ ).

Sebagiam teknik pelatihan yang paling efektif mencakup: 
1. Icebreakers (memecahkan ketegangan) dan energizers (membangkitkan semangat)

\section{Persentasi interaktif}

3. Memeberikan pertanyaan dan memberikan dorongan

4. Menuangkan pikiran

5. Diskusi kelompok

6. Studi kasus

7. Memainkan peranan

8. Simulasi

9. Permainan (Usmara, 2006 : 90).

Sebagaibagian dari usaha meningkatkan kesejahteraan sosial rakyatnya, pemerintah suatu Negara menempuh berbagai cara dan menetapkan berbagai kebijaksanaan dibidang ketenagakerjaan. Salah satu bentuknya ialah menyelenggarakan pelatihan di berbagai balai latihan kerja. Balai latihan kerja tersebut pada umumnya mempunyai tugas pokok melatih sejumlah warga sehingga memiliki keterampilan teknis yang benar-benar siap pakai. (Siagian, 2009 : 124).

Siagian menegaskan peranan berbagai balai latihan itu akan semakin penting apabila

a. Para penyelenggara memiliki informasi yang lengkap dan muktahir tentang permintaan akan tenaga teknis tertentu di pasaran kerja sehingga program pelatihan yang diselenggarakan benar-benar tertuju pada pemenuhan permintaan di pasaran kerja.

b. Para lulusan betul-betul merupakan tenaga kerja yang siap pakai sehingga segera setelah diterima sebagai pegawai, mereka lansung dapat berkarya secara produktif.

c. Terjalin kerja sama antara berbagai balai latihan kerja itu dengan berbagai organisasi/perusahaan pemakai tenaga kerja. (Siagian, 2009 : 125).

Menurut Rachmawati program pelatihan dan pengembangan merupakan salah satu kegiatan yang penting dan dijadikan salah satu investasi organisasi dalam organisasi dalam hal sumber daya manusia.(Rachmawati, 2008 : 110).

Kamus Besar Bahasa Indonesia pendidikan berasal dari kata didik, lalu kata ini mendapat awalan kata me sehingga menjadi mendidik artinya memelihara dan memberi latihan. Dalam memelihara dan memberi akhlak dan kecerdasan pikirian. (Kamus Besar Bahasa Indonesia, $1991: 232$ ). 
Sedangkan menurut Undang-Undang Nomor 20 Tahun 2009 tentang Pendidikan Nasional, pendidikan adalah usaha sadar dan terencana untuk mewujudkan suasana belajar dan proses pembelajaran agar peserta didik secara aktif mengembangkan potensi dirinya untuk memiliki kekuatan spiritual, keagamaan, penegndalian diri, kepribadian, kecerdasan, akhlak mulia, serta keterampilan yang diperlukan dirinya, masyarkat bangsa dan Negara.

Menurut Saydam pembinaan berarti pembaharuan, penyempurnaan atau usaha, tindakan atau kegiatan yang dilaksanakan secara berdaya guna dan berhasil guna untuk memperoleh hasil yang lebih baik. (Saydam, 2000 : 408).

Saudjana menyatakan pembinaan dapat diartikan sebagai upaya memelihara membawa suatu keadaan yang seharusnya terjadi atau menjaga keadaan sebagaimana seharusnya. Dalam manajemen pendidikan, pembinaan dilakukan dengan maksud agar kegiatan atau program yang sedang dilaksanakan selalu sesuai dengan rencana atau tidak menyimpang dari yang telah direncanakan. Apabila pada suatu waktu terjadi penyimpanganpenyimpangan maka dilakukan upaya untuk mengembalikan kegiatan kepada yang seharusnya dilaksanakan atau kembali ke perencanaan semula. (Saudjana, 2000 : 223).

Saudjana juga menegaskan pembinaan diartikan sebagai rangkaian upaya pengendalian secara profesional terhadap semua unsur organisasi agar unsur-unsur tersebut berfungsi sebagaimana mestinya sehingga rencana untuk mencapai tujuan dapat terlaksana secara berdaya guna dan berhasil guna. (Saudjana, $2000: 223$ ).

Menurut Thoha mengartiakn pembinaan sebagai suatu tindakan, proses, hasil atau pernyataan lebih baik, dalam hal ini menunjukan adanya kemajuan peningkatan, pertumbuhan, evaluasi atas berbagai kemungkinan, berkembang atau peningkatan atas suatu hal. (Thoha, $2004: 7$ ).

Sedangkan menurut Pamudji (dalam Thoha, 2004 : 12) mengartikan pembinaan adalah sebagai pembangunan yaitu mengubah sesuatu sehingga menjadi baru yang memiliki nilai-nilai lebih tinggi. Dengan demikian, pembinaan juga mengandung makna sebagai pembaharuan yaitu : melakukan usaha-usaha untuk menjadi lebih sesuai atau lebih cocok dengan kebutuhan menjadi lebih baik.

Widodo mendefinisikan pembinaan adalah suatu usaha yang dilakukan secara teratur dan terarah serta bertanggung jawab untuk mengembangkan kepribadian pengetahuan dan keterampilan untuk mencapai tujuan yang telah ditentukan. (Widodo, 1984 : 23). 


\section{METODE PENELITIAN}

Tipe penelitian yang digunakan adalah metode penelitian Survey, dengan tingkat eksplanasi Deskriptif serta menggunakan analisis data Kuantitatif dan Kualitatif.Pengertian survey umumnya dibatasi pada penelitian yang datanya dikumpulkan dari sampel atas populasi untuk mewakili seluruh populasi. (Masri Singarimbun dan Sofian Efendi, 2008 : 3). Menurut Sugiyono penelitian kuantitatif adalah analisa data memakai angka-angka dan penelitian kualitatif adalah penelitian yang digunakan untuk meneliti pada kondisi obyek yang alamiah, (sebagai lawannya adalah eksperimen) dimana peneliti adalah sebagai instrument kunci, teknik pengumpulan data dilakukan secara triangulasi (gabungan), analisa data bersifat induktif, dan hasil penelitian kualitatif lebih menekankan makna dari pada generalisasi. (Sugiyono, $2012: 1$ ).

Penentuan Responden pada orang yang akan diberikan kuisioner dilakukan secara random sampling dan Key Informan yang akan diwawancarai dilakukan secara purposive sampling, yaitu dipilih dengan pertimbangan dan tujuan tertentu. Adapun Responden dan Key Informan dalam penelitian ini, sebagai berikut :

Tabel 1. Sampel Penelitian Dari Unsur Perangkat Desa

\begin{tabular}{|c|l|c|c|c|}
\hline \multirow{2}{*}{ No } & \multicolumn{1}{|c|}{ Nama Responden } & \multicolumn{2}{c|}{ Jumlah } & \multirow{2}{*}{$\begin{array}{c}\text { Persentase } \\
\%\end{array}$} \\
\cline { 2 - 4 } 1 & $\begin{array}{l}\text { Perangkat Desa Pemerintahan Desa } \\
\text { Benai Kecil }\end{array}$ & 15 & 13 & $86 \%$ \\
\hline 2 & $\begin{array}{l}\text { Perangkat Desa Pemerintahan Desa } \\
\text { Tebing Tinggi }\end{array}$ & 15 & 12 & $80 \%$ \\
\hline 3 & $\begin{array}{l}\text { Perangkat Desa Pemerintahan Desa } \\
\text { Koto Simandolak }\end{array}$ & 15 & 14 & $93 \%$ \\
\hline & Jumlah & 45 & 39 & $86 \%$ \\
\hline
\end{tabular}

Sumber : Modifikasi Peneliti Tahun 2017

Tabel 2. Informasi Kunci Dari Unsur Pegawai Kantor Camat Benai

\begin{tabular}{|c|l|c|c|}
\hline \multirow{2}{*}{ No } & \multirow{2}{*}{ Unsur Responden } & \multicolumn{1}{|c|}{ Jumlah } & Persentase \\
\cline { 3 - 3 } & & \multicolumn{1}{|c|}{ Key Informan } \\
\hline \multirow{2}{*}{1} & $\begin{array}{l}\text { Pegawai Kantor } \\
\text { Camat Benai }\end{array}$ & Camat Benai & $100 \%$ \\
\cline { 3 - 4 } & Kumlah & Kasi Pemerintahan Desa & $100 \%$ \\
\hline & Jumlah & $100 \%$ \\
\hline
\end{tabular}

Sumber : Modifikasi Peneliti Tahun 2017

Pengumpulan data dapat dilakukan dari berbagai setting, sumber dancara. Teknik pengumpulan data yang digunakan dalam penelitian ini adalah kuisioner, observasi, wawancara, studi dokumentasi dan gabungan dari keempatnya atau triangulasi.(Sugiyono, 
2012 : 62-63). Analisa data dilakukan pada peneltian ini adalah setelah semua data yang telah diperoleh dalam penelitian lalu dikumpulkan, selanjutnya dikelompokkan untuk dijadikan sebagai bahan masukan yang akan digunakan dalam pelaksanaan penulisan ini. Setelah data tersebut diolah, selanjutnya penulis akan melakukan pembahasan terhadap data yang bersifat kuantitatif dan kualitatif dalam bentuk deskriftif dengan menganalisa secara seksama lalu menarik kesimpulan dan pada akhirnya memberikan saran-saran.

\section{PEMBAHASAN}

1. Pelatihan (Training) Mengenai Tertib Administrasi Pemerintahan Desa

Pelatihan (training) merupakan suatu proses pembelajaran yang melibatkan perolehan keahlian, konsep, peraturan atau sikap untuk meningkatkan keterampilan. Pelatihan juga dimaksudkan memperbaiki penguasaan berbagai keterampilan dan teknik pelaksanaan kerja tertentu, terinci dan rutin. Kegiatan pelatihan sangat penting karena bermamfaat guna menambah pengetahuan atau keterampilan terutama bagi yang bekerja langsung dengan pengadministrasian.Bagi yang sudah bekerja bukan berarti pelatihan tidak penting, malah pelatihan bermamfaat untuk mengasah kemampuan kembali.

Sementara itu apabila dilihat dari tanggapan perangkat desa untuk mengetahui apkah pelatihan secara formal maupun non formal pernah dilaksanakan oleh Pihak Pemerintahan Kecamatan Benai kepada desa-desa.Hal tersebut dapat dilihat dari jawaban responden seperti data pada tabel di bawah ini :

Tabel 3. Jawaban Responden dari Unsur Perangkat Desa Terhadap PelaksanaanPelatihan

\begin{tabular}{|c|l|c|c|c|c|}
\hline \multirow{2}{*}{ No } & \multicolumn{1}{|c|}{ Item Yang Dinilai } & $\begin{array}{c}\text { Ada/ } \\
\text { Selalu }\end{array}$ & $\begin{array}{c}\text { Ada/ } \\
\text { Jarang }\end{array}$ & $\begin{array}{c}\text { Tidak } \\
\text { ada }\end{array}$ & Jumlah \\
\hline \multirow{2}{*}{1} & Pelatihan (Training) Formal & $\begin{array}{c}13 \\
33 \%\end{array}$ & $\begin{array}{c}17 \\
44 \%\end{array}$ & $\begin{array}{c}9 \\
23 \%\end{array}$ & $\begin{array}{c}39 \\
100 \%\end{array}$ \\
\hline \multirow{2}{*}{2} & Pelatihan (Training) Non Formal & 8 & 25 & 6 & 39 \\
& $21 \%$ & $64 \%$ & $15 \%$ & $100 \%$ \\
\hline \multirow{2}{*}{} & Jumlah & 21 & 42 & 15 & 78 \\
\cline { 2 - 6 } & Rata-Rata & 10 & 21 & 8 & 39 \\
\cline { 2 - 6 } & Persentase (\%) & $25 \%$ & $54 \%$ & $21 \%$ & $100 \%$ \\
\cline { 2 - 6 } & Standar Kategori & \multicolumn{4}{|c}{$54 \%$} \\
\cline { 2 - 6 } & Kriteria Pengukuran & \multicolumn{4}{|c|}{ Kurang Berperan } \\
\hline
\end{tabular}

Sumber : Data Olahan Penelitian 2017 
2. Peninjauan (Monitoring) Setalah Pelatihan (Training) Mengenai Tertib Administrasi Pemerintahan Desa

Menurut Kamus Besar Bahsa Indonesia Pusat Bahasa Edisi Keempat monitoring adalah pengwasan dan tindakan memverifikasi kebenaran operasi suatu program selama pelaksanaannya berdasarkan rutin diagnostik yang digunakan dari waktu ke waktu untuk menjawabpertanyaan tentang pertanyaan tersebut. Monitoring dilakukan ketika sebuah kegiatan sedang diimplementasikan atau yang telah dilaksankan agar kesalahan-kesalahan awal dapat segera diketahui dan dapat dilakukan tindakan perbaikan, sehingga mengurangi resiko yang lebih besar.

Pengawasan adalah salah satu fungsi manajemen untuk menjamin agar pelaksanaan kerja berjalan sesuai dengan standar yang telah ditetapkan dalam perencanaan. Apabila pelaksanaan kerja berjalan tidak sesuai dengan standar perencanaan, walaupun secara tidak sengaja tetap kearah yang lebih baik, hal ini tampak klasik dan tradisonal, disebut lepas kontrol. Dengan demikian melalui pengawasan dapat diawasi sejauh mana penyimpangan, penyalahgunaan, kebocoran, kekurangan, pemborosan, kemubaziran, penyelewengan, dan lain-lain dimasa yang akan datang. Jadi keseluruhan pengawasan adalah aktivitas membandingkan apa yang sedang atau yang sudah dikerjakan dengan apa yang direncanakan sebelumnya. Oleh karena itu diperlukan kriteria, norma, standar, dan ukuran.

Untuk lebih jelasnya apakah pihak Pemerintahan Kecamatan Benai ada melakukan peninjauan (monitoring) secara berkala maupun tidak berkala peneliti melakukan penyebaran kuisoiner dan melakukan wawancara, dapat dilihat pada tabel dan kutipan wawancara di bawah ini :

Tabel 4. Frekuensi Jawaban Responden dari Unsur Perangkat Desa Mengenai Peninjauan (Monitoring) Yang Dilakukan Oleh Pihak Pemerintah Kecamatan Benai

\begin{tabular}{|c|l|c|c|c|c|}
\hline \multirow{2}{*}{ No } & \multicolumn{1}{|c|}{ Item Yang Dinilai } & $\begin{array}{c}\text { Ada/ } \\
\text { Selalu }\end{array}$ & $\begin{array}{c}\text { Ada/ } \\
\text { Jarang }\end{array}$ & $\begin{array}{c}\text { Tidak } \\
\text { Ada }\end{array}$ & Jumlah \\
\hline \multirow{2}{*}{1} & Peninjauan (Monitoring) Berkala & 13 & 18 & 8 & 39 \\
& & $33 \%$ & $46 \%$ & $21 \%$ & $100 \%$ \\
\hline \multirow{2}{*}{2} & $\begin{array}{l}\text { Peninjauan (Monitoring) Tidak } \\
\text { Berkala }\end{array}$ & $\begin{array}{c}19 \\
49 \%\end{array}$ & $\begin{array}{c}11 \\
28 \%\end{array}$ & $\begin{array}{c}9 \\
23 \%\end{array}$ & $\begin{array}{c}39 \\
100 \%\end{array}$ \\
\hline \multirow{3}{*}{} & Jumlah & 32 & 29 & 17 & 78 \\
\cline { 2 - 6 } & Rata-Rata & 16 & 15 & 8 & 39 \\
\cline { 2 - 6 } & Persentase (\%) & $41 \%$ & $39 \%$ & $20 \%$ & $100 \%$ \\
\cline { 2 - 6 } & Standar Kategori & \multicolumn{4}{|c|}{ Berperan } \\
\cline { 2 - 6 } & Kriteria Pengukuran & \multicolumn{4}{|c|}{} \\
\hline
\end{tabular}

Sumber : Data Olahan Penelitian 2017 


\section{Evaluasi (Evaluation) Mengenai Tertib Administrasi Pemerintahan Desa}

Evaluasi biasanya ditujukan untuk menilai sejauh mana kesuksesan sebuah kegiatan, guna dipertanggungjawabkan kepada pihak terkait.Sejauh mana tujuan dicapai, maka evaluasi diperlukan untuk melihat kesenjangan antara "harapan" dengan "kenyataan".

Evaluasi adalah kegiatan untuk menilai tingkat suatu kegiatan.Evaluasi membuahkan pengetahuan yang relevan dengan kegiatan tentang ketidak sesuaian antara yang diharapkan dengan yang benar-benar dihasilkan.Evaluasi tidak hanya menghasilakan kesimpulan mengenai seberapa jauh masalah telah terselesaikan, tetapi juga menyumbang pada klarifikasi dan kritik terhadap nilai-nilai yang mendasari suatu kegiatan, membantu dalam penyesuain dan perumusan kembali masalah yang terjadi.Untuk lebih jelasnya apakah pihak Pemerintahan Kecamatan Benai ada melakukan evaluasi (evaluation) secara berkala maupun tidak berkala peneliti melakukan penyebaran kuisoiner dan melakukan wawancara, dapat dilihat pada tabel dan kutipan wawancara di bawah ini :

Tabel 5. Frekuensi Jawaban Responden dari Unsur Perangkat Desa Mengenai Evaluasi (Evaluation) Yang Dilakukan Oleh Pihak Pemerintah Kecamatan Benai

\begin{tabular}{|c|l|c|c|c|c|}
\hline \multirow{2}{*}{ No } & \multicolumn{1}{|c|}{ Item Yang Dinilai } & $\begin{array}{c}\text { Ada/ } \\
\text { Selalu }\end{array}$ & $\begin{array}{c}\text { Ada/ } \\
\text { Jarang }\end{array}$ & $\begin{array}{c}\text { Tidak } \\
\text { Ada }\end{array}$ & Jumlah \\
\hline \multirow{2}{*}{1} & Evaluasi (Evaluation) Berkala & 9 & 11 & 19 & 39 \\
& \multirow{2}{*}{2} & $23 \%$ & $29 \%$ & $48 \%$ & $100 \%$ \\
\hline \multirow{2}{*}{ Evaluasi (Evaluation) Tidak Berkala } & 8 & 17 & 14 & 39 \\
& Jumlah & 17 & 28 & 33 & 78 \\
\cline { 2 - 6 } & Rata-Rata & 8 & 14 & 17 & 39 \\
\cline { 2 - 6 } & Persentase (\%) & $21 \%$ & $36 \%$ & $43 \%$ & $100 \%$ \\
\cline { 2 - 6 } & Stabdar Kategori & \multicolumn{4}{|c}{ Tidak Berperan } \\
\cline { 2 - 6 } & Kriteria Pengukuran & \multicolumn{4}{|c|}{} \\
\hline
\end{tabular}

Sumber : Data Olahan Penelitian 2017 
4. Rekapitulasi Jawaban Responden Penelitian Tentang Peranan Camat dalam Membina Administrasi Pemerintahan Desa di Kecamatan Benai Kabupaten Kuantan Singingi

\begin{tabular}{|c|l|c|c|c|c|}
\hline \multirow{2}{*}{ No } & \multicolumn{1}{|c|}{ Indikator } & Berperan & $\begin{array}{c}\text { Kurang } \\
\text { Berperan }\end{array}$ & $\begin{array}{c}\text { Tidak } \\
\text { Berperan }\end{array}$ & Jumlah \\
\hline \multirow{2}{*}{1} & \multirow{2}{*}{ Pelatihan (Training) } & 21 & 42 & 15 & 78 \\
& \multirow{2}{*}{2} & $27 \%$ & $54 \%$ & $19 \%$ & $100 \%$ \\
\hline \multirow{2}{*}{3} & Peninjauan (Monitoring) & 32 & 29 & 17 & 78 \\
\multirow{2}{*}{ Evaluasi (Evaluation) } & $17 \%$ & $37 \%$ & $22 \%$ & $100 \%$ \\
\hline Jumlah & $22 \%$ & 28 & 33 & 78 \\
\hline Rata-Rata & 70 & 99 & 65 & 234 \\
\hline Persentase \% & 23 & 33 & 22 & 78 \\
\hline Standar Kategori & $29 \%$ & $43 \%$ & $28 \%$ & $100 \%$ \\
\hline Kriteria Pengukuran & \multicolumn{5}{|c|}{$43 \%$} \\
\hline
\end{tabular}

5. Hambatan Pelaksanaan Tugas Camat Dalam Pembinaan Administrasi Pemerintahan Desa Di Kecamatan Benai Kabupaten Kuantan Singingi

Dalam pelaksanaan tugas dan wewenang Camat dalam Peraturan Pemeritah Nomor 19 Tahun 2008 Tentang Kecamatan Pasal 15 Ayat 1 dan 2 masih terdapat hambatan yang dialami, yaitu sebagai berikut :

1. Keterbatasan Sumber Daya Manusia dalam membina terkait dengan administrasi pemerintahan desa.

2. Keterbatasan pendanaan terkait dengan pembinaan karena memerlukan biaya operasional.

3. Kurangnya pro aktif dan perhatian dari Desa yang ada terkait dengan pembinaan administrasi pemerintahan desa.

4. Tingkat kemaun untuk maju masih rendah.

5. Kurang nya kerja sama antar lembaga terkait.

6. Solusi Hambatan Terhadap Pelaksanaan Tugas Camat Dalam Pembinaan Administrasi Pemerintahan Desa Di Kecamatan Benai Kabupaten Kuantan Singingi

Solusi dari kendala ataupun masalah yang ada antaralain :

1. Merencanakan tim SDM untuk melaksanakan pembinaan terkait dengan tertib administrasi pemerintahan desa.

2. Membuat perencanaan terkait dengan pembinaan yang akan dilakukan kepada pemerintahan desa.

3. Melakukan kerjasama dengan pihak terkait agar terjalin sinergisitas. 
4. Diberi pelatihan yang memadai kepada pegawai kantor camat agar bisa menjadi instruktur internal.

5. Meningkatkan evaluasi dalam meningkatkan kualitas pemerintahan desa terkait tertib administrasi pemerintahan desa.

\section{KESIMPULAN}

Berdasarkan hasil penelitian dan analisa yang telah dilakukan mengenai Peranan Camat dalam Membina Administrasi Pemerintahan Desa di Kecamatan Benai Kabupaten Kuantan Singingi, maka dapat ditarik kesimpulan dari penelitian ini yang dinilai dari indikator penelitian yakni pelatihan (training), peninjauan (monitoring) dan evaluasi (evaluation) secara keseluruhan dirasakan belum berjalan maksimal atau kurang berperan.

\section{DAFTAR PUSTAKA}

Departemen Pendidikan Nasional. (2008). Kamus Besar Bahasa Indonesia Pusat Bahasa Edisi Keempat. Jakarta: PT. Gramedia Pustaka Utama.

Hamalik, Oemar, (2001). Pengembangan Sumber Daya Manusia Manajemen Pelatihan Ketenagakerjaan Pendekatan Terpadu. Jakarta: PT Bumi Aksara.

Usmara, A. (2006). Praktik Manajemen SDM: Unggul Melalui Orientasi \& Pelatihan Karyawan. Yogyakarta: Santusta.

Masri Singarimbun dan Sofian Efendi (editor). (2008). Metode Penelitian Survai. Jakarta: LP3ES Indonesia.

Narwoko, J. Dwi \& Bagong Suyanto. (2004). Sosiologi Teks Pengantar Dan Terapan, Jakarta: Kencana Prenada Media Group.

Rachmawati, Ike Kusdyah. (2008). Manajemen Sumber Daya Manusia. Yoyakarta: Andi. Saudjana. (2000). Program Pendidikan. Bandung: Falah Production.

Saifuddin, Ahmad Fedyani. (2005). Antropologi Konyemporer Suatu Pengantar Kritis Mengenai Paradigma. Jakarta: Kencana Prenada Media Group.

Saydam, Gouzali. (2000). Manajemen Sumber Daya Manusia. Jakarta: Djembatan.

Siagian, Sondang P. (2009). Manajemen Sumber Daya Manusia. Jakarta: PT. Bumi Aksara.

Sugiyono. (2012) Memahami Penelitian Kualitatif. Bandung: CV. Alfabeta. . (2014). Metode Penelitian Administrasi. Bandung: Penerbit Alfabeta. 
Thoha, Miftah. (2004). Pembinaan Organisasi. Jakarta: PT. Raja Rafindo Persada.

Widodo, Adnan. (1984). Pola-Pola Orang Pemerintahan. Jakarta: PT. Maju Jaya.

\section{Peraturan - Peraturan :}

Undang - Undang Dasar Negara Republik Indonesia Tahun 1945

Undang - Undang Nomor 1 Tahun 1945 tentang Kedudukan Komite Nasional Daerah

Undang - Undang Nomor 22 Tahun 1948 tentang Pemerintahan Daerah

Undang - undang Nomor 44 Tahun 1950 tentang Pemerintahan Daerah Negara Indonesia Timur (NIT)

Undang - undang Nomor 1 Tahun 1957 tentang Pokok - pokok Pemerintahan Daerah Undang - undang Nomor 18 Tahun 1965 tentang Pokok - Pokok Pemerintahan Daerah

Undang - Undang Nomor 5 Tahun 1974 tentang Pokok - Pokok Pemerintahan Daerah Undang - Undang Nomor 22 Tahun 1999 tentang Pemerintahan Daerah

Undang - undang Nomor 32 Tahun 2004 tentang pemerintahan daerah

Undang - Undang Nomor 25 Tahun 2009 tentang Pelayanan Publik

Undang - Undang Nomor 23 Tahun 2014 tentang Pemerintah Daerah

Peraturan Pemerintah Nomor 19 Tahun 2008 Tentang Kecamatan 